\author{
Ана М. ЈАњУШЕВИЋ ОЛИВЕРИ* \\ Универзитет у Приштини \\ са привременим седиштем \\ у Косовској Митровици \\ Филозофски факултет
}

Оригинални научни рад

Примљен: 02. 11. 2018.

Прихваћен: 14. 02. 2019.

\title{
ДОМАЋИН И ДОМАЋИЦА У КОНТЕКСТУ СРПСКОГ ЈЕЗИКА
}

\begin{abstract}
У раду се испитује лексичко-семантичка вриједност лексема̂ домаћин и домаћица у савременом српском језику. Премда је примарно значење обију лексема 'онај/она који/ која управља домом', полисемантичка структура ријечи домаћин и домаћица не почива на истим семантичким реализацијама. Стога је и циљ рада да опише значења ових лексема и да утврди контекстуалне услове који проузрокују разлике у њиховим семантичким вриједностима.

Кључне ријечи: домаћин, домаћицฺ, полисемија, семантичка реализација, значење, сема.
\end{abstract}

0. Лексеме домаћин и домаћийа припадају деривационом гнијезду лексеме дом, чији су другостепени деривати. ${ }^{1}$ Од ове основе испитиване лексеме су наслиједиле и полисемантичку структуру базирану на двјема основним семама, које дом показују као физички објекат, односно зграду, с једне, и као друштвену заједницу, с друге стране (Ристић/Лазић Коњик).

На основу примарног значења - 'онај/она који/која управља домом', али и на основу моционог суфикса додатог истој основи, ${ }^{2}$ могло би се закључити да се ове двије лексеме разликују само према обиљежју мушко/женско. Међутим, већ рјечнички опис показује да се број и врста секундарних значења испитиваних лексема разилазе, те је циљ овог рада да на конкретним

\footnotetext{
*anna.janjusevic@gmail.com

${ }^{1}$ Именице домаћин и домаћица изведене су од придјева домаћи, који такође представља дериват именице дом. О деривационом гнијезду лексеме дом - в. Ђуровић 2004.

${ }^{2}$ Мисли се на суфиксе -ин и -ица који су додати основи домаћ-. Посебно је питање настанка придјева домаћи, које би, с обзиром на неусаглашености и нејасноће у досадашњим тумачењима, захтијевало посебну елаборацију, што, свакако, превазилази оквире овог рада.
} 
примјерима ексцерпираним из различитих извора (Електронски корпус, интернет-странице и језик писаца) прво опише сва значења лексема домаћин и домаћица у савременом српском језику, а потом и да укаже на контекстуалне услове који проузрокују разлике у семантичким реализацијама ових ријечи.

1. Полазна тачка овог истраживања јесу лексикографски описи лексема домаћин и домаћица у Речнику српскохрватског књижевног и народног језика (РСАНУ).

1.1. Полисемантичка структура лексеме домаћин представљена је на сљедећи начин: 1. а. онај који управља кућом, домом, глава породице, старешина задруге, газда; б. онај који брижљиво и уредно води своје домаћинство, чуваран, штедљив човек; в. покр. онај који има добро имање, имућан човек, газда; 2. а. онај који некога прима као госта; б. онај који се стара о организацији неког скупа, свечаности, прославе; в. спорт. клуб, екипа на чијем се терену одиграва нека утакмица; 3. муж, супруг; 4. надзорник, настојник (обично неке веће јавне зграде); 5. биолошки: организам на коме живи неки други организам или паразит (РСАНУ 4: 513-514).

Примарно значење је дато под 1а. и одређује домаћина у односу на кућу/ дом, породицу, задругу. ${ }^{3}$ Значења 1б. и 1в. откривају аксиолошке карактеристике и дају информације о начину управљања домом и о самој личности домаћина. Значења наведена под 2. почивају на релационим семантичким обиљежјима и описују однос домаћина као неког ко је на сопственом терену према госту (а), односно према другим учесницима неког дешавања (укључујући под в. и спортска дешавања). Трећа семантичка реализација заснива се на релацији муж-жена. Значење под 4. изведено је из примарног значења и почива на семи „онај који нечим управља”, док се посљедња семантичка реализација - паразит наслања на релацију домаћин-гост. Значења под 1. и 2. припадају семантичком језгру лексеме домаћин, док су преостала три периферна.

1.2. Лексема домаћица показује мању семантичку разуђеност у односу на лексему домаћин, а њена семантичка структура у РСАНУ (4: 515) приказана је на сљедећи начин: 1. а. жена која води домаћинство, обавља кућне послове и сл. б. домаћинова жена; в. жена домаћин; 2 а. она која прима неког као госта; б. власница гостионице, гостионичарка; 3. покр. учесница у свадбеном обреду, деверова жена или рођака; 4. агр. покр. врста крушке; 5. (у атрибутској служби, уз именице ж. рода) заст. домаћа; родна.

Интересантно је да се у РСАНУ каже да домаћица води домаћинство, док домаћин управљь д домаћинством. Додуше, у значењу под 1в. наводи се да домаћица може преузети и улогу домаћина. Прва два значења почивају на истим релацијама код обију лексема, док су им остала, периферна, различита.

2. На основу лексикографског описа лексема̂ домаћин и домаћицุa закључујемо да се њихов семантички садржај базира на два типа односа. Први се тиче улоге у односу на породицу/домаће/укућане или, у ширем смислу, у

\footnotetext{
${ }^{3}$ Сматрамо да газда није адекватан синоним за овако интерпретирано примарно значење лексеме домаћин. Адекватнији синоним би био старјешина; газда се, осим тога, наводи као синоним и у значењу 1в.
} 
односу на заједницу. Други однос открива садржаје који су у вези са домаћинством/домом, односно у вези са простором који се доживљава као свој.

2.1. Номинационо значење лексеме домаћин, како показују рјечници, организовано је на принципу платисемије, ${ }^{4}$ а почива на архисеми друштвене улоге - домаћин је човјек, односно особа која управља неком заједницом или пословима у домаћинству. Дајемо предност дефиницији према којој је домаћин о с о ба, јер домаћин не мора бити обавезно мушкарац, о чему свједоче и примјери из Ћосићевог романа Корени:

Prerovci su ga prezirali i ismejavali. Mati $\mathrm{i}^{5}$ je bila domaćin kuće, a on je uvek bio njen sluga i vodeničar. Kao da joj nije bio muž i čovek (ЕК: Ћосић, Корени); Ona kuću drži, imanjem upravlja, u trgovini pomaže. On a je domaćin, a ne Aćim, koji na stranku i politiku rastura njegovu muku (ЕК: Ћосић, Корени).

2.1.1. Улога у односу на заједницу реализује се првенствено кроз примарно значење (1) глАВА ПОРОДИЦЕ/СТАРЈЕШИНА:

Za sto prvo sedaju stariji, i to najpre domaćin, s njegove desne strane brat, pa onda po starešinstvu ostali [...] (ЕK: Требјешанин, Представа о детету у српској култури); [...] i to najpre se pričesti domaćin, pa onda svi muški, pa svi ženski u kući (EK: Чајкановић, Речник српских народних веровања о биљкама); Svi domaćini, starešine srpskih porodica i zadruga, ujedinjavali su se u jednu radnu zajednicu (EK: Петрановић, Србија у Другом светском рату).

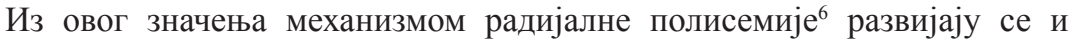
остала, мање или више контекстуално условљена значења. У контексту именовања супружника домаћин поприма данас већ архаично значење (2) муж:

Prvog muža ona je do smrti zvala „moj domaćin” (ЕК: Ћосић, Корени); [...] nijednoj svojoj drugarici nije zavidela što se, i mlađa od nje, odavno u da la, već joj domaćin počeo da se bogati i ona ulazila u red imućnih žena, gazdarica (ЕК: Станковић, НК).

Грађа показује да семантички потенцијал лексеме домаћин у односу на заједницу којој припада превазилази ове двије улоге. Домаћин је и (3) свАКи ОСАМОСТАљЕНИ МУШКАРАЦ:

[...] veselje posle slave svršavalo strašnom kockom na kojoj su, po običaju, oni, njihni mu š ki, kao domaćini, sveta i običaja radi, po čitave njive i vinograde gubili (EK: Станковић, НК); On je već veliki, već domaćin, s v oj g o s p o d a r... (ЕК: Станковић, Јовча); Pored m l a d o g domaćina Dragana i njegove supruge Dragane, uz nadničare su i starij i domaćin Miloš zvani Braša, domaćica Nada i baba Desa (EK: Политика 24. 9. 2000),

\footnotetext{
${ }^{4}$ Д. Гортан-Премк (1996: 77) платисемију дефинише као широкозначност, односно способност лексеме да у својој номинационој реализацији именује два веома слична појма.

${ }^{5}$ Спационирањем се у свим примјерима истиче ријеч или група ријечи у улози индикатора семантичке позиције у којој се реализује одређено значење. Под семантичком позицијом, слиједећи Д. Гортан-Премк (2004: 49), подразумијевамо мјесто реализације лексеме у линеарном поретку ријечи.

${ }^{6}$ При радијалној полисемији секундарна значења настају из примарног (Драгићевић 2010: 133).
} 
али и (4) МУШКИ ПОТОМАК/НАСљЕДНИК:

„Kaži mu da odmah kući dođe: domaćin mu se rodi o.” Tako mu je poručila mati (EK: hосић, Корени); DECA: Nano, nano, dade nam baka cveće. TAŠANA (grli de c u): O, o, gle moji domaćini već mi došli! (ЕК: Станковић, Ташана).

У вези са номинационим значењем и архисемом друштвене улоге јављају се и периферна значења: (5) човЈЕК, одНОСНО чОВЈЕК иЗ НАРОДА:

Reći ću ti odmah nešto i želim da ovo upamtiš: tebe sam, kao svog ujaka i čestitog domaćina, vazda volio i poštovao [...] (ЕК: Драшковић, Молитва друга); [...] nego kaže da si ti okupatorski sluga i izdajnik srpskog naroda i da za p ošte n e domaćine i rodoljube nije da se sa takvim govnima druže! (ЕК: Пекић, Одбрана и последњи дани); Tomislav Nikolić je č o v e k i z n a r o d a, pravi srpski domaćin, uvažavan i poštovan od svakog ko iskreno ceni tradicionalne srpske vrednosti i borbu za slobodu [...] (ЕК: Политика, 17. 8. 2000);

и (6) ПОљОПРИВРЕДНИК/СЕљАК:

Domaćini kažu da na kraju zime ne očekuju zaradu, ali ni gubitak. Pre svega im je važna dobra reklama (ЕК: РТС 2. 11. 2010); А домаћини су народ! [...] Дабоме, домаћини к о ј и св оју земљу раде и радом децу своју ране (Поповић 2007: 71-72); И ти си ми Србин! Шумадинац! Солунац! С ељак! Домаћин! - стаде он опет да набраја (Поповић: 131).

2.1.2. Други дио платисемички организованог примарног значења лексеме домаћин открива улогу домаћина у односу на домаћинство са физичким карактеристикама које се тичу првенствено омеђеног простора.

2.1.2.1. Тако је домаћин (1) чОВЈЕК/МУШКАРАЦ КОЈИ УПРАВљА ДОМАЋИНСТВОМ, и кога одликује искључиво позитивна аксиолошка конотација - углед, брижљивост, љубав према раду:

Domaćin obično upravlja kućom i imanjem dok ima snage i sposobnosti da obavlja svoj odgovorni zadatak (ЕК: Требјешанин, Представа о детету у српској култури); Dobri domaćini već na izmaku leta misle na zimu i zimnicu, ali i novčanik (EK: PTC, 18. 8. 2010); Ministar zdravlja nije krio zadovoljstvo uz komentar da je „domaćin dobar ka da mu je ambar pun" (ЕК: Политика, 4. 8. 2000).

Из овог значења механизмом радијално-ланчане полисемије ${ }^{7}$ развијају се и остала. Домаћин је и (2) човЈеК коли УПРАВљА не само својим домаћинством Него и БИЛО КОЈОМ ЗГРАДОМ/ИНСТИТУцИЈОМ:

Dosta je bilo priče, ja više nisam domaćin u ovom Institutu, ovu veliku i tešku odgovornost preuzeo je moj naslednik [...] (ЕК: Политика, 1. 9. 2000).

2.1.2.2. Други тип значења, када је у питању однос према одређеном простору, базира се на семи посједовања, те је домаћин (3) ОНАЈ коли пОсЈЕдуЈЕ домАћинство, односно посједник или газда:

Vrlo je imućan domaćin. Ima divnu svoju zemlju, prikupljenu i od dedova nasleđenu (ЕК: Божовић, Косовске приче); [...] ви сте, вели, и мали с воје ку ее и своју

\footnotetext{
7 Ланчана полисемија подразумијева процес при коме се из примарног развија секундарно, из секундарног терцијарно значење итд. (Драгићевић 2010: 133).
} 
с току, били сте домаћии у Србији (Поповић 2007: 45); [...] bili su samo žitelj i zemlje koju su držali, a ne i, „domaćini” (ЕК: Николић, Древноруско словенско право).

Из овог су се лексичком метонимијом развила и значења (4) БоГАТ ЧОВЈЕК:

A oni, pravi domaćini, puna im kuća berićeta a uz to i dobri ljudi (ЕК: Божовић, Теби, моја Долорес); Сав мој годишњи рад не вреди колико једна плата пандурска, а овако, ја ти као неки домаћин дођем (Поповић: 72-73);

или пак (5) чОВЈЕК КОЈИ СТИЧЕ:

I zato je otac pred babom uvek radosno, od sveg srca činio se mali, ne on da je domaćin kuće, gazda, da don os i (ЕК: Станковић, Газда Младен).

2.1.2.3. На семи просторног одређења заснива се и значење (6) човЈек, ОДНОСНО ОРГАНИЗАЦИЈА НА ЧИЈЕМ СЕ ТЕРЕНУ НЕШТО ДЕШАВА. ОВа семанТИЧка реализација нарочито је честа у спортском жаргону, када се домаћином назива спортска екипа на чијем терену се одиграва утакмица:

[...] a to ne bi dobra donelo ni vama ni meni, jer ste vi ovde domaćini, a ja opet ne dam sebi suviše blizu nikome ... (ЕK: Секулић, Кроника);

Zabranjeno je organizovati, finansirati ili biti domaćin b o r b e između životinja iste ili različitih vrsta (ЕК: Закон о ветеринарству); Država članica - domaćin K ong re sa, uz dogovor sa Međunarodnim biroom, predlaže koje osobe treba imenovati za Doajena Kongresa (EK: Закон о потврђивању аката светског поштанског савеза); Beograd je bio domaćin Prve konferencije državnika nesvrstanih zemalja (EK: Стекић-Симић, Наш крах - Београд и околина);

Rival našoj selekciji u četvrtom kolu je ekipa Ukrajine, a u poslednjem, petom domaćin - A reprezentacija Poljske (EK: Политика, 6. 8. 2000); Domaćin došao do pobede golom Benčivenge devet sekundi pre kraja susreta (EK: Политика, 7. 8. 2000); Doтаćin Oli mpijskih ig a ra je pobedio našeg današnjeg rivala sa $88: 80$ (EK: Политика, 12. 9. 2000).

На истој семи, уз релациону семантичку црту према лексеми гост, почИва и ЗНачење (7) чОВЈЕК/ОРГАНИЗАЦИЈА КОЈИ/КОЈА НЕКОГА ПРИМА У ГОСТЕ:

Koga su citirali, a u korist svojih teza, g o s t i domaćin? (ЕК: Киш, Пешчаник); N e z v a ni gost je bio prinuđen da sa domaćinom popije nekoliko čašica ljute (EK: Политика, 10. 1. 2001);

Domaćini raseljenih lica sa Kosova i Metohije od „Intersosa” će dobiti materijal za adaptaciju kuća [...] (EK: Политика, 25. 8. 2000); [...] pozivno pismo ili potvrda o upisu koju šalje univerzitet, koledž ili š k ola domaćin, ili studentske knjižice, ili potvrde o kursevima koji će biti pohađani [...] (ЕК: Закон о потврђивању сарадње између Републике Србије и Владе Бугарске).

Из ове се семантичке реализације лексичком метафором развило и значење (8) ОРГАНИЗАМ НА КОМЕ ЖИВИ ПАРАЗИТ:

Imele su poluparaziti sa zelenim listovima, koji se učvršćuju za biljku domaćina sisaljkama [...] (ЕК: Јанчић, Ботаника фармацеутика).

У неким контекстуалним условима, а при употреби плурала, домаћин се изједначава са деадјективном именицом домаћи, тј. домаћини су (9) они коли живе у дому/кУЋи. 
Mali, pospani domaćini u prozoru bi ostavljali čiste cipelice u koje bi sveti Nikola spuštao poklone (ЕК: Илустрована политика); Na kapiji zveknu alka. - Domaćini! Čak gore ču Sofka jak glas sa oštrim i stranim naglaskom (ЕК: Станковић, НК).

У вези са семом просторне детерминације је и семантичка реализација (10) ОРГАНИЗАТОР НЕКОГ ДЕШАВАњА, јер се подразумијева да домаћин може бити само онај ко организује догађај на терену коме на неки начин припада:

Ali, neka nervoza spopade domaćine ve selj a, jer se termin odlaska kod matičara približio, a kum kao da je propao u zemlju (ЕК: Политика 25. 1. 2001); [...] po istom postupku, puštaju svoje j. niz trpezu domaćin s va dbe, dever, kum i vojvoda (ЕК: Чајкановић, Речник српских народних веровања о биљкама); Voditelj i domaćin ve čeri svake noći na Kanlikuli biće glumac Goran Sultanović (ЕК: Политика, 7. 8. 2000); Kako su novine zapisale, domaćin slave 1930. bio je Miloje Aračić, nekadašnji poslanik i vlasnik velikih ribnjaka (EK: Голубовић, Из механе и кафане старог Београда).

2.2. Лексема домаћица свој семантички садржај такође реализује у односу на дом схваћен као заједницу и као простор, односно домаћинство. Такву слику показује рјечнички опис у којем је примарно значење структурирано на принципу платисемије и састављено из релационих семантичких обиљежја која показују - 1) однос жена-дом/кућа и 2) однос жена-муж.

Међутим, примјер:

- Kad si sposoban, koju si izabrao? - D e v oj k a je zdrava, lepa, dobra domaćica... Takvu bi mi i ti izabrao (ЕК: Ћосић, Корени) -

показује да домаћица не мора бити домаћинова жена, тј. није нужно удата, те је боље као номинационо истаћи значење женски члан породице који се стара о домаћинству.

2.2.1. У односу на породицу или у ширем смислу на зај е дн и цу, лексема домаћица остварује се у четири значења, и то:

(1) СУПРУГА:

Ovo je ta, „,efendi-Mitina kuća”. Ovo je moja domaćica, a ovo je moja kći, moja Sofka [...] (ЕК: Станковић, НК); - A gde vam je domaćica? - E, bila, pa je nema - razveo ruke Mirko, ali kao u šali. - Dodijao sam joj mladoj ja (ЕК: Секулић, Кроника);

(2) глАВА ПоРодицЕ, али само уколико је одсутан домаћин:

- Alo, polako! Ostala je sama, još je mlada, a domaćica, pokušaj da razumeš kevu - ladi je Hari (ЕК: Ђурђевић, Леш у фундусу);

\section{(3) НЕЗАПОСЛЕНИ ДИО ЖЕНСКЕ ПОПУЛАЦИЈЕ}

Za n i m a n je? Sudija. A drugarica? Jelena se nasmeši: Doтаćica. (ЕК: Албахари, Судија Димитријевић); „Моja ma ma ne radi ništa. Ona je domaćica” (EK: Politika, 3. 9. 2000); Otac Vukašin bio je policajac, majka Milica - domaćica (ЕК: Политика, 17. 12. 2000); [...] kada je broj zaposlenih žena (15.180.000) prešao broj domaćica (15.160.000). Tada su i Japanci shvatili da žene neminovno izlaze iz kuhinje (ЕК: Политика, 19. 3. 2001); и 
(4) УОПШТЕНО, ЖЕНА ИЗ НАРОДА:

U Selištu, pošto sam žurio, jedna domaćica mi je upakovala zaklanu kokošku da ponesem svojoj kući (...) (ЕК: Политика, 6. 2. 2002); Krupna kao planina, još krepka i jako jedra kao i mnoge bogate s e $1 \mathrm{j}$ a č k e domaćice i srećne majke koje su poženile i razudale, ona plavno koračaše niz ledinu (ЕК: Божовић, Косовске приче).

2.2.2. Када је у питању однос домаћица-домаћинство/простор, издвајају се три основне семантичке реализације, чија се значења даље гранају захваљујући метафоричним и метонимијским механизмима.

2.2.2.1. Тако је домаћица (1) жЕнА коЈА води дом, односно управља домом, када је њен најближи синоним лексема газдарища:

[...] kada će i ona, kao i njene udate drugarice, imati svoju kuću i u njoj biti domaćica, sa mužem ići po rodbini, po slavama, večerama, kao i po saborima [...] (ЕК: Станковић, HK); [...] ja tu imam jedno jutro zemlje, koje se više ne može obrađivati - kaže Sofija. Ova preduzimljiva domaćica natkrila je izvorište, gde u minutu izlazi oko 120 litara kvalitetne vode za piće [...] (ЕК: Политика, 11. 9. 2010); S na lažlj iv ost domaćica i njihovo umeće ekonomisanja u domaćinstvima sa prosečnim primanjima su veoma važna (EK: Политика, 21. 6. 2001).

Из овог се развија и значење засновано на аксиолошким аспектима - домаћица је (2) ВРИЈЕДНА/СПОСОБНА ЖЕНСКА ОСОБА:

[...] gleda me kako ne znam šta ću, i vadi iz tašne profi DHL kesu, sa lepljivom trakom, domaćica žen a, rekla sam već (ЕК: Ђурђевић, Трећи сектор).

Ако се дом схвати као омеђен простор, улога се модификује, те се домаћицом Може НаЗваТИ и (3) ЖЕНА КОЈА УПРАВљА НЕКОМ ОРГАНИЗАЦИЈОМ:

Svi su se prosjaci nje bojali. Naročito na groblju. Tamo im je bila kao neka domaćica. U r e điv a la ih je, pazila da ko čije mesto ne zauzme (ЕК: Станковић, Божји људи); Zvaničan naziv ove ustanove je Klub za dnevni boravak starih lica na Savskom vencu. Domaćica kluba Ruža Oljača svoj posao radi već godinama [...] (ЕК: Политика, 25. 7. 2001).

\subsubsection{2. Друга семантичка реализација у односу на дом схваћен као} омеђен простор јесте (4) ЖЕНА КОЈА ОБАВљА КУЋНЕ ПОСЛОВЕ, при чему се у највећем броју примјера домаћица изједначава са особом која се бави кухињом, ${ }^{8}$ али и распремањем простора: ${ }^{9}$

A ona? Kao i svaka uzorna domaćica: pere, pegla, sprema ručak i čeka da svih desetoro dođe i poseda oko stola (ЕК: Политика, 13. 10. 2007); Četrnaest mladih domaćica u

\footnotetext{
${ }^{8}$ Ова семантичка реализација при којој се домаћица доживљава као жена која добро припрема храну, и то уз минималан утрошак намирница вјероватно је послужила као инспирација за именовање кекса фабрике „Краш”. Касније је то посао општи назив за танко чајно пециво преливено чоколадом.

Домаћицом, кућаницом или зидњаком називане су и зидне поруке које су у ранијим временима везене и качене изнад шпорета и умиваоника да би заштитиле зид од уља, односно од воде. Претпостављамо да је и ово именовање у вези са основном улогом домаћице, жене која обавља кућне послове, првенствено оне везане за кухињу.

${ }^{9}$ О продуктивности значења 'жена која обавља кућне послове' говори и чињеница да је и апарат на пару намијењен чишћењу у домаћинству назван домаћица. Ово значење је забиљежено у Речнику нових речи (Клајн 1992: 91).
} 
četrnaest koliba spremalo je za svakog zasebno po jedan kus-kus od prosa (ЕК: Петровић, Африка); Tirnanić me, prezrivo kvalifikuje kao domaćicu. Jesam domaćica, odlično i redovno kuvam, pa se ne hranim i ne trujem ni po elitnim ni inim restoranima (ЕК: НИН, 28. 3. 2002); [...] ku p ovin a pogrešnih namirnica, pogrešan način pripremanja j ela, najčešće su greške naših domaćica - kaže profesorka Ružić [...] (ЕК: Политика, 17. 6. 2001); Svež kupus na tezgama staje 10, a u većini prodavnica je oko šest dinara. Ukoliko domaćica odluči da k u p i praziluk treba joj još 20 ili 25 dinara za kilogram, koliko staje i rotkva (ЕК: Политика, 20. 1. 2001).

Из овог се значења развила и семантичка реализација (5) кућнА помоћНИЦА:

Njegova majka bila je jednostavna žena, domaćica kuć e još dok je prva očeva žena bila živa. Otac se njome oženio jedva godinu dana posle ženine smrti, kada je ova domaćica već očekivala dete (ЕК: Јеротић, Психоанализа, болест, стварање); U okviru službe „Pomoć u kući” u 13 gradskih opština usluge g e r o n t o-domaćica sada koristi oko 2000 starih Beograđana [...] (ЕК: Политика, 2. 11. 2007).

Уколико се кућни послови схвате као мање важни или чак безвриједни у односу на неке друге, лексема домаћица у таквим контекстима реализује значење (6) МАњЕ ВРИЈЕДНЕ, НЕПРОСВЕЋЕНЕ ЖЕНЕ. То показује и горе наведени примjep: Tirnanić me, prezrivo kvalifikuj e kao domaćicu, али и неки други:

[...] dobio nagrade, a onda mu jedna obična domaćica prigovara! (ЕК: НИН, 28. 3. 2002); Uvek je smatrano da je to drugorazredni spektakl, koji ugađa ubog om u kus u domaćica (ЕК: Политикин културни додатак, 2001); Oni koji poseduju stvarnu moć nikada se ne prikazuju u javnosti, to bar svaka domaćica zna! (ЕК: НИН, 27. 6. 2002).

2.2.2.3. Када је у питању одређење према простору на коме се нешто дешава, лексема домаћица показује знатно мање семантичких реализација. Мали је број примјера у којима се истиче релација домаћица-гост, када се домаћицом Назива (7) ЖЕНА КОЈА НЕКОГ ПРИМА У ГОСТЕ:

[...] jedne večeri, posle predstave Sonate duhova u Dramskom pozorištu, m o ja me domaćica o dv e d e u Kraljevsku biblioteku (ЕК: Киш, Енциклопедија); Dok nas nu d i pravo m domać om šljivovicom, bezbedno pohranjenom u burence, naša domaćica sa ustezanjem govori o sebi (ЕК: Политика, 17. 9. 2000).

Сема просторног одређења домаћицу показује првенствено као (8) жЕну КОЈА ОРГАНИЗУЈЕ ДЕШАВАњЕ ИЛИ ПаК Учествује У њемУ:

Marja Gregorovna Popko, žena visokog carskog činovnika i domaćica ove fe š te, pomalo napadno obučena, razvija svoju lepezu i prilazi Nataliji Sergejevnoj [...] (ЕК: Киш, Ноћ и магла); Dobrodošlicom na srpskom i engleskom jeziku, domaćin i domaćica-v o d it e lj i p ro grama pros lave, obratili su se uglednim gostima i svim prisutnim [...] (ЕК: Православље); Domaćica več eri otvaranja i zatvaranja 63. Kanskog festivala bila je Kristin Skot Tomas [...] (ЕК: Политика, 24. 5. 2010).

У вези са овим значењем је и новија употребе лексеме домаћица у спортском жаргону, гдје се домаћицом назива најчешће (8) спортскА ЕкипА која добро игра једино на свом, тј. на домаћем терену:

Aruka nema poraz kod kuće i važi za pravu domaćicu (ИК: Моцарт); Рarana je prava domaćica, koja u gostima ne stoji baš najbolje (ИК: Моцарт). 
Рјеђе се лексема домаћица употребљава да означи женски спортски клуб који је домаћин меча. Тако тумачимо појаву ове ријечи у наслову: Srpkinje ubedljive protiv 'domaćica' [полунаводници се налазе у оригиналном тексту], јер текст открива сљедеће: Srpske odbojkašice su bile dominantne u Ankari [...] (ИК: Смедиа).

На семи просторног одређења заснован је и ботанички термин домаћица као назив за крушку, која, претпостављамо, расте на домаћем поднебљу. Таквих примјера нема у нашој грађи, али се лексема домаћица (9) у вријЕдности ПридлевА домАћи јавља у вези са музиком. О томе свједочи и емисија домаће музике на МТВ-у, а исту ријеч у значењу 'домаћа поп музика' биљежи и С. Милорадовић (2012: 257).

3. Преглед сакупљеног материјала показао је да обје посматране лексеме имају више семантичких реализација него што то показују рјечници српског језика. Разлог томе лежи свакако у чињеници што је већина тих значења заснована на семама колективне експресије, које не улазе обавезно у лексикографски опис (Драгићевић 2010: 72).

У закључку ћемо резимирати семантичку структуру посматраних лексема и указати на разлике у њиховим семантичким реализацијама.

3.1. Да је лексема домаћин семантички разуђенија, показује и број значења потврђених у овој анализи. Она има шеснаест семантичких реализација, док лексема домаћица, укључујући и новија жаргонска образовања, остварује дванаест значења. Саму прерасподјелу семантичких реализација илуструје сљедећа табела:

\begin{tabular}{|l|c|c|}
\hline \multicolumn{1}{|c|}{ значење } & домаћин & домаћица \\
\hline глава породице & + & + \\
\hline супружник & + & + \\
\hline управља домаћинством & + & + \\
\hline управља институцијом & + & + \\
\hline организатор дешавања & + & + \\
\hline $\begin{array}{l}\text { организација на чијем терену } \\
\text { се нешто дешава }\end{array}$ & + & + \\
\hline прима неког у госте & + & - \\
\hline човјек/жена из народа & + & - \\
\hline осамостаљени члан породице & + & + \\
\hline потомак/насљедник & + & - \\
\hline незапослени дио популације & - & - \\
\hline посједник & + & + \\
\hline богат човјек & + & + \\
\hline
\end{tabular}




\begin{tabular}{|l|c|c|}
\hline сељак/пољопривредник & + & - \\
\hline онај који живи у дому/кући & + & - \\
\hline обавља кућне послове & - & + \\
\hline мање вриједна особа & - & + \\
\hline организам на коме живи паразит & + & - \\
\hline
\end{tabular}

Табеларни преглед значења показује да се анализиране лексеме разликују у периферним значењима (с изузетком значења „обавља кућне послове”, карактеристичног само за лексему домаћица), док она која припадају семантичком језгру одликују обје ријечи.

3.2. Лексема домаћин има већи број значења и због тога што се у појединим семантичким позицијама показује неутралном у погледу изражавања природног рода. Тако се лексемом домаћин, означава глава породице, било да је ријеч о мушкарцу или о жени која је старјешина дома или пак, употријебљена у множини, ријеч домаћини односи се и на и мушке и на женске житеље куће.

Обје лексеме показују већу продуктивност сема које детерминишу домаћина/домаћииу у односу на дом схваћен као простор него у односу на дом са значењем породице/заједнице. Код лексеме домаћин тај однос је $6: 10$, а код лексеме домаћица $4: 8$. Да ове семе имају још потенцијала за развијање нових значења, говоре и нова значења лексеме домаћица у спортском и музичком жаргону.

3.3. Разлике у периферним значењима лексема̂ домаћин и домаћицุа углавном су условљене употребом у специфичним контекстима. Тако је, на примјер, очекивано да лексема домаћин, употријебљена уз глагол родити се има значење „насљедник”. Лексема домаћица је маркирана могућношћу да изрази занимање жене која није запослена, док се, с друге стране, мушкарац истог статуса, ако није пољопривредник, означава само придјевом „незапослен”. Нисмо наишли ни на један примјер у коме би контекст показао домаћииу као особу која посједује дом/домаћинство, што је још једна важна културолошки условљена разлика у односу на лексему домаћин. Интересантно је да лексема домаћица може попримити и негативну аксиолошку конотацију, што је такође диференцира у односу на лексему домаћин, која је у свим контекстима позитивно конотирана.

\section{ИЗВОРИ}

ЕК: Електронски корпус савременог српског језика (http://www.korpus.matf.bg.ac.rs/korpus/korpus2013adv.php)

ИК, Моцарт: https://www.mozzartsport.com, 22. X 2018.

ИК, Смедиа: http://www.smedia.rs/sport/, 22. Х 2018.

Поповић: Д. Поповић, Кюига о Милутину, Београд: Књига комерц, 2007. 


\section{ЛИТЕРАТУРА}

Гортан Премк 2004: Д. Гортан-Премк, Полисемија и организачија лексичког система у српскоме језику, Београд: Завод за уџбенике и наставна средства.

Драгићевић 2010: Р. Драгићевић, Лексикологија српског језика, Београд: Завод за уџбенике.

Ђуровић 2009: С. Ђуровић, Деривационо гнездо лексеме дом, творбено-семантичка анализа, Naučni trudove - filologija, tom 46, kn. 1, zbornik A, Plovdiv: Plovdivski universitet „Paisij Chilendarski”, 465-478.

Ђуровић 2013: С. Ђуровић, Синонимски пар кућа : дом у српском језику, Српски језик, XVIII, 329-338.

Клајн 1992: И. Клајн, Речник нових речи, Нови Сад: Матица српска.

Милорадовић 2012: С. Милорадовић, Музички жаргон младих и молодежный музыкальный сленг. Компаративни поглед, Београд: Етнографски институт САНУ.

Ристић 2015: С. Ристић, Граматички и когнитивни аспекти лексичког значењ $а$, Београд: Институт за српски језик.

Ристић/Лазић Коњик: С. Ристић, И. Лазић-Коњик, Дом у српском језику, www.rastko.rs./projekti/etnoling/delo/14705 (19. III 2018).

РСАНУ 4: Речник српскохрватског књижевног и народног језика, књ. 4, Београд: САНУ, 1966.

Ana Janjušević Oliveri

\section{LEXEMES DOMAĆIN AND DOMAĆICA IN THE CONTEXT OF THE SERBIAN LANGUAGE}

\section{Summary}

This paper aims to evaluate the lexical and semantic value of the lexemes domaćin and domaćica (Eng. householder) in the contemporary Serbian language. Although the primary meaning of both lexemes is the same 'the one who manages a household', the polysemantic structure of the words domaćin and domaćica do not have the same semantic realization. The research has shown that the lexeme domaćin has a more diversified semantic realisation of the polysemantic structure. These dfferences are noticeable in the secondary meanings, which are often heavily contextualised.

Key words: domaćin, domaćica, polysemy, semantic realisation, meaning, semantic component. 